\title{
Study on Flowering Characters of Bottle gourd (Lagenaria siceraria) by Training and Pinching
}

\author{
C. Ciba ${ }^{1 *}$ and M. Syamala ${ }^{2}$ \\ ${ }^{1}$ Department of Vegetable Crops, HC\&RI, Tamil Nadu Agricultural University, \\ Coimbatore-641003, Tamil Nadu, India \\ ${ }^{2}$ Department of Plant Pathology, Tamil Nadu Agricultural University, Coimbatore-641003, \\ Tamil Nadu, India \\ *Corresponding author
}

\begin{tabular}{|c|c|}
\hline \multicolumn{2}{|r|}{ A B S T R A C T } \\
\hline & \multirow{5}{*}{$\begin{array}{l}\text { Field experiment was carried out at the orchard of Department of Vegetable Crops, } \\
\text { Horticultural College and Research Institute, Tamil Nadu Agricultural University, } \\
\text { Coimbatore during } 2010-2011 \text { to find out the effect of training and pinching on flowering } \\
\text { characters of bottle gourd (Lagenaria siceraria } \mathrm{M} \text {.) } \mathrm{cv} \text {. } \mathrm{CBgH}_{1} \text {. The different types of } \\
\text { pinching on secondary laterals were imposed up to } 3^{\text {rd }} 4^{\text {th }}, 5^{\text {th }} \text { and } 6^{\text {th }} \text { node and control (no } \\
\text { pinching on secondary laterals) in the experiment. Among the treatments, pinching on } \\
\text { secondary laterals at } 6^{\text {th }} \text { node proved to be superior in respect to flowering characters. The } \\
\text { highest number of female flowers per plant }(20.4 \& 20.6) \text {, was noted and days to first male } \\
\text { appearance }(32.2 \& 32.3) \text {, days to first female appearance }(45.1 \& 44.6) \text {, node at first } \\
\text { female appears }(14.4 \& 14.1) \text {, number of male flowers per vine }(84.60 \& 85.20) \text { and sex } \\
\text { ratio }(4.15 \& 4.14) \text { were recorded significantly reduced in plants received pinching on } \\
\text { secondary laterals at } 6^{\text {th }} \text { node }\left(\mathrm{T}_{4}\right) \text {. }\end{array}$} \\
\hline & \\
\hline $\begin{array}{l}\text { Flowering characters, } \\
\text { Bottle gourd, Training } \\
\text { and pinching. }\end{array}$ & \\
\hline Article Info & \\
\hline $\begin{array}{l}\text { Accepted: } \\
\text { 24 September } 2017 \\
\text { Available Online: } \\
\text { 10 November } 2017\end{array}$ & \\
\hline
\end{tabular}

\section{Introduction}

Bottle gourd (Lagenaria siceraria M.) is valued for its nutritive and medicinal properties. The fruit has protein $(0.2 \mathrm{~g})$, carbohydrate $(2.5 \mathrm{~g})$ and traces of minerals like calcium (20mg), phosphorus (10mg) and iron $(0.7 \mathrm{mg})$ in $100 \mathrm{~g}$ of fruit (Thamburaj and Singh, 2000). Its tender fruits are used as cooked vegetable and also for making sweets in Africa and Asia. Bottle gourd is a highly cross-pollinated crop due to its andromonoecious nature and has a wide genetic diversity. Being a cross-pollinated crop, it has wide range of variability for maturity, yield and fruit characters like shape and size (Sidhu 2002). The recent past development of small fruited hybrids made the crop to grow in bower system of cultivation as like other cucurbits viz., snake gourd, bitter gourd and ribbed gourd. This made the researchers to develop training and pruning techniques to maximize the yield.

The research on effect of training and pinching to improve the growth and flowering characters like in bottle gourd is very scanty and it has to be standardized for various environments. This paper reports the effect of training and pinching on secondary lateral at 
$6^{\text {th }}$ node significantly improved the flowering attributes of bottle gourd.

\section{Materials and Methods}

The experiment was conducted for two seasons from July 2010 to Nov 2010 and from Jan 2011 to May 2011 in RBD with five treatments in four replications. Seeds were sown in pits at the spacing of $2.0 \times 2.0 \mathrm{~m}$.

The removal of all auxiliary buds from $1^{\text {st }}$ to $10^{\text {th }}$ node up to 25-30 days after sowing were made to maintain single stem leader. The apical bud was pinched just $10 \mathrm{~cm}$ below the bower and allowed only two primary branches to trail on the pandal. From that primary laterals pinching was excised on $5^{\text {th }}$ node to allow more secondary branches. On the secondary laterals, the treatments were imposed up to $3^{\text {rd }}, 4^{\text {th }}, 5^{\text {th }}$ and $6^{\text {th }}$ node and control as follows:

$\mathrm{T}_{1}$ - Pinching on secondary lateral at $3^{\text {rd }}$ node $T_{2}$ - Pinching on secondary lateral at $4^{\text {th }}$ node $\mathrm{T}_{3}$ - Pinching on secondary lateral at $5^{\text {th }}$ node $\mathrm{T}_{4}$ - Pinching on secondary lateral at $6^{\text {th }}$ node $\mathrm{T}_{5}$ - No pinching on secondary lateral shoots (control)

\section{Results and Discussion}

The researchers all over the world have devoted considerable attention to maximize the production of bottle gourd by the use of innovative technologies of training and pinching practices for improved varieties. In the present study, the bottle gourd prerelease cultivar $\mathrm{CBgH}_{1}$ was chosen to standardize the effect of training and pinching on flowering parameters.

Table.1 Effect of training and pinching on days to first male and female appearance in bottle gourd

\begin{tabular}{|c|c|c|c|c|c|c|}
\hline \multirow{2}{*}{ Treatments } & \multicolumn{3}{|c|}{ Days to first male appearance } & \multicolumn{3}{c|}{ Days to first female appearance } \\
\cline { 2 - 7 } & Season I & Season II & Mean & Season I & Season II & Mean \\
\hline $\mathrm{T}_{1}$ & 32.6 & 32.7 & 32.7 & 45.3 & 44.9 & 45.1 \\
\hline $\mathrm{T}_{2}$ & 32.7 & 32.4 & 32.6 & 45.4 & 45.4 & 45.4 \\
\hline $\mathrm{T}_{3}$ & 32.8 & 32.6 & 32.6 & 45.2 & 45.3 & 44.9 \\
\hline $\mathrm{T}_{4}$ & 32.2 & 32.3 & 32.3 & 45.1 & 44.6 & 45.3 \\
\hline $\mathrm{T}_{5}$ & 32.3 & 32.5 & 32.4 & 45.2 & 46.6 & 45.7 \\
\hline SED & $\mathbf{0 . 6 9}$ & $\mathbf{0 . 5 9}$ & $\mathbf{0 . 4 5}$ & $\mathbf{0 . 7 0}$ & $\mathbf{0 . 9 2}$ & $\mathbf{0 . 5 8}$ \\
\hline $\mathbf{C D}(\mathbf{P = 0 . 0 5})$ & --- & --- & --- & --- & -- & $\cdots$ \\
\hline
\end{tabular}

Table.2 Effect of training and pinching on node at first female appears and number of male flower per vine in bottle gourd

\begin{tabular}{|c|c|c|c|c|c|c|}
\hline \multirow{2}{*}{ Treatments } & \multicolumn{3}{|c|}{ Node at first female appears } & \multicolumn{3}{c|}{ Number of male flowers per vine } \\
\cline { 2 - 7 } & Season I & Season II & Mean & Season I & Season II & Mean \\
\hline $\mathrm{T}_{1}$ & 14.4 & 14.1 & 14.2 & 98.75 & 98.15 & 98.75 \\
\hline $\mathrm{T}_{2}$ & 14.7 & 14.4 & 14.5 & 89.20 & 89.15 & 89.18 \\
\hline $\mathrm{T}_{3}$ & 14.4 & 14.4 & 14.4 & 84.85 & 85.55 & 85.20 \\
\hline $\mathrm{T}_{4}$ & 14.4 & 14.1 & 14.2 & 84.60 & 85.20 & 84.90 \\
\hline $\mathrm{T}_{5}$ & 14.2 & 14.6 & 14.4 & 116.75 & 115.19 & 116.45 \\
\hline SED & $\mathbf{0 . 2 4}$ & $\mathbf{0 . 4 0}$ & $\mathbf{0 . 2 3}$ & $\mathbf{1 . 0 6}$ & $\mathbf{0 . 4 0}$ & $\mathbf{0 . 5 7}$ \\
\hline $\mathbf{C D}(\mathbf{P}=\mathbf{0 . 0 5})$ & --- & --- & --- & $\mathbf{2 . 3 2}$ & $\mathbf{0 . 8 8}$ & $\mathbf{1 . 1 7}$ \\
\hline
\end{tabular}


Table.3 Effect of training and pinching on number of female flowers and sex ratio in bottle gourd

\begin{tabular}{|c|c|c|c|c|c|c|}
\hline \multirow{2}{*}{ Treatments } & \multicolumn{2}{|c|}{ Number of female flowers per vine } & \multicolumn{3}{c|}{ Sex ratio } \\
\cline { 2 - 7 } & Season I & Season II & Mean & Season I & Season II & Mean \\
\hline $\mathrm{T}_{1}$ & 16.30 & 16.50 & 16.40 & 6.05 & 5.98 & 6.02 \\
\hline $\mathrm{T}_{2}$ & 17.60 & 17.87 & 17.74 & 5.06 & 4.98 & 5.02 \\
\hline $\mathrm{T}_{3}$ & 18.33 & 18.22 & 18.27 & 4.61 & 4.69 & 4.65 \\
\hline $\mathrm{T}_{4}$ & 20.35 & 20.58 & 20.46 & 4.15 & 4.14 & 4.14 \\
\hline $\mathrm{T}_{5}$ & 15.55 & 15.53 & 15.54 & 7.50 & 7.48 & 7.49 \\
\hline SED & $\mathbf{0 . 2 0}$ & $\mathbf{0 . 1 3}$ & $\mathbf{0 . 1 2}$ & $\mathbf{0 . 0 5 8}$ & $\mathbf{0 . 0 5 8}$ & $\mathbf{0 . 0 4 1}$ \\
\hline CD(P=0.05) & $\mathbf{0 . 4 4}$ & $\mathbf{0 . 3 0}$ & $\mathbf{0 . 2 5}$ & $\mathbf{0 . 1 2 7}$ & $\mathbf{0 . 1 2 7}$ & $\mathbf{0 . 0 8 5}$ \\
\hline
\end{tabular}

In the present study, days to first male appearance, days to female flower appearance and the node at which first female flower appears did not show any appreciable variation due to pinching on main stem in all the treatments (Table 1). The appearance of first male or female flowers had occurred in the main stem or primary branch itself, even before pinching, hence these pinching had not had any effect of first female or male flower appearance. This result is in conformity with the results reported by Rasco and Castilo (1990) in bitter gourd. The ultimate goal to be achieved in any crop production is maximization of yield. The yield contributing character such as number of fruits and fruit yield play a vital role in productivity. The number of female flowers and number of fruits are important yield contributing characters. In the present study, more female flowers were produced in the pinched plants and is highest on secondary lateral at $6^{\text {th }}$ node (Table 2 ). The increase in number of tertiary branches due to pinching, favouring the production of female flowers in the basal nodes might have actailas become one among the factors to produce more number of female flowers per vine. The arrest in apical dominance might have check and this will in turn reduce the auxin and there is an increase of florigen or cytokinin like compounds in the vine. This is being well matched with available food resource of C:N ratio by higher rate of photosynthesis and accumulation of photosynthates due to it fact of more number of leaf, leaf area and efficiencies might had made this higher numbers of female flowers production (Table 3).This is in conformity with the results reported by Singh and Mangal (1982) in muskmelon, where it was stated that training and pinching improves the exposure of leaves to sun light which results in an increased trapping of the solar energy for production of carbohydrate content in shoots. Increase in carbohydrate content narrows the $\mathrm{C}$ : $\mathrm{N}$ ratio and higher metabolic activity which leads to switching from vegetative to reproductive buds (Fieller and Leschke 1970) in cucumber.

\section{References}

Fieller B and Leschke F 1970 Cucumber pruning as factor influencing the yield. Dtsche Gartenals, 16:186-189.

Rasco OA and Castillo SP 1990Flowering patterns and vine pruning effects in bitter gourd. Philippine Agriculturist 73(4): 311-322.

Sidhu AS 2002 Current status of vegetable research in India, Tropical seed.com; Publication and Research: Articles.

Singh Band Mangal JL 1982Effect of pruning, spacing and fertilizer levels on flowering, fruiting, yield and quality of muskmelon. Haryana J. Hort. Sci.12 (1):64-68.

Thamburaj S and Singh N 2000 Vegetables, tuber crops and spices. ICAR Publication, New Delhi.p.271-278.

\section{How to cite this article:}

Ciba C. and Syamala, M. 2017. Study on Flowering Characters of Bottle Gourd (Lagenaria siceraria) by Training and Pinching. Int.J.Curr.Microbiol.App.Sci. 6(11): 3326-3328.

doi: https://doi.org/10.20546/ijcmas.2017.611.390 